\title{
A Research Agenda for the Retrofitting of Residential Buildings in China - A Case Study
}

Andrew N. BALDWIN* 1, Dennis L. LOVEDAY 2, Baizhan LI 1, Michael MURRAY3, YU Wei 1

1 Faculty of Urban Construction and Environmental Engineering, Chongqing University, Chongqing 400045, PR China.

2 School of Civil and Building Engineering, Loughborough University, Loughborough, LE11 3TU, UK

3Fulcro Engineering Services, Leicester, UK

This item was submitted to Loughborough University's Institutional Repository by the/an author. Research article: Energy Policy, Volume 113, February 2018, Pages 41-5, published by Elsevier Please cite the published version.

\begin{abstract}
The high-rise residential buildings of China will soon need retrofitting and any such retrofitting should include consideration of new energy saving methods and 'green' technologies. A research agenda is needed to meet this challenge. This paper presents a research agenda for the 'green' retrofitting of residential buildings. The agenda is based on the input of 25 national and international experts which was produced by a novel methodology specifically designed to discuss the key questions relating to the retrofitting of residential buildings. This methodology, based on Problem Tree Analysis, proved an effective method of producing an agenda for the research that is needed to facilitate such change. The research needs are presented under six headings. Stages for undertaking the research activities under each of these headings have been identified. The agenda highlights that the challenge of retrofitting is holistic and includes not just engineering and construction actions but economic, social and governmental requirements. Key aspects of the research agenda include the need for better macro-economic and micro-economic models and a better understanding of people's needs and expectations. These topics are discussed together with recent research findings both from China and other countries.
\end{abstract}

Keywords: residential, retrofit, reconstruction, sustainable buildings, retrofit policy

\section{Introduction}

The pace of change in the towns and cities of China has been rapid. Between 1980 and 2014 China's economic success has resulted in the growth of the urban population from 191 million to 749 million [1]. Such an increase is unprecedented in modern times. In only 30 years the level of urbanization has risen from 20\% to today's 54\%. By 2030 it is estimated that Chinese cities will be home to about 1 billion people, approximately $70 \%$ of the country's population. Despite the current slow-down in the Chinese economy urbanization and the movement of the people to the cities will continue: urbanization is the main enabler for the reduction of poverty and is the basis of the country's development potential [2]. 
The majority of the urban population in China live in high-rise residential buildings. (We define high-rise residential buildings as buildings of more than eight storeys high.) This form of housing is now the predominant residential model for all the main cities of China. Prior to 1990 the industrial cities of China typically housed residents in 5 or 6 story work-unit type residential housing often linked to specific industrial units. The majority of these residences were designed and constructed in the late 1970s and 1980s and are now being demolished.

Rapid urbanization has caused great pressures on energy, resources and the environment [3]. Building energy demands have increased dramatically [4] [5] and continue to increase. Experience from other countries indicates that buildings in developed countries contribute some $35-40 \%$ of the energy use of a country [6]. As in other countries, new buildings in China need to be designed to be energy efficient and constructed with 'green' technologies to make best use of depleting resources and reduce carbon emissions.

Notwithstanding the challenge of constructing new buildings to new energy standards there is now increasing recognition in China that the high cost of demolishing and rebuilding existing buildings means that consideration must now be given to refurbishment and retrofitting. (In China the commonly accepted term is 'reconstruction'.) Where existing buildings need to be reconstructed a reduction in operational energy requirements is a priority. This applies to all building types: government buildings, public buildings, (commercial and retail buildings), and residential buildings. Residential apartments in China are usually acquired with leases of between 50 and 70 years' duration. If these buildings are to last anywhere near this timespan they are likely to require major retrofitting at least once in their lifetime if they are not to deteriorate to a state which will make them un-inhabitable long before their anticipated end of life. Previous research, [7] [8] has shown that retrofitting is not just a technical issue but a socio-economic issue. The authors of this paper were unaware of any holistic research agenda for the retrofitting of residential buildings in China. This was the impetus for their research.

Retrofitting may be undertaken at several levels: a light touch or renewal; medium intervention; extensive intervention; comprehensive refurbishment; and demolition [9]. The action required at any point in the building's life-time will depend upon the performance and the condition of the building. Extensive intervention requires the full replacement of some parts of the building, building-fabric changes, plus re-modelling building services to meet current building standards and 'future proofing' the building for the next 20-25 years. Whilst not always the primary reason for retrofitting, any retrofitting should include full consideration and renewal of the energy systems for the building. This may be termed 'deep energy retrofitting'. With deep energy retrofitting the entire fabric and conventional systems of the building have to be evaluated, redesigned and reconstructed in an integrated way. Airtightness of the building envelope is imperative if substantial energy savings are to be made [10].

Achieving this level of performance on existing buildings is not easy [10]. This will be a major challenge for the construction industry in China, an industry that has up to this moment in time been predominantly focused on the construction of new buildings. New technologies, new skills and new business processes will need to be developed. Given the need for reducing 
carbon dioxide output and reducing the impact of the construction industry it is considered that any discussion should be based on a low-carbon or Green Building construction approach [11]. This approach, also known as Sustainable Building includes consideration of durability; the energy required for heating; the energy required for cooling; the potential for using renewable energy; impact on daylight; environmental impact; indoor air quality and acoustics; structural stability, fire safety; aesthetic quality; effect on cultural heritage; life-cycle cost; need for ongoing care and maintenance; disturbance to tenants and the site; buildability, etc. [12].

What are the requirements for the low-energy, 'green' retrofitting of high-rise residential buildings in China? To discuss these requirements a workshop meeting of international experts was held in the city of Chongqing China. To ensure that their thinking was grounded in the context of China the meeting also included experts from the city of Chongqing and other parts of China. Other senior national and regional government officials and industry representatives provided contextual information to assist the experts' discussions. The aim of the workshop was to develop a research agenda for the green retrofitting of residential buildings in China. The objectives were: to identify the problems of retrofitting residential buildings their causes and their effects; to propose a framework of research objectives; and to provide a basis for reviewing existing research and identifying new research questions and new research projects.

This paper describes the methodology used at the workshop event and key aspects from the findings that now provide a research agenda for retrofitting residential buildings in China. The findings from the workshop are presented and discussed in the context of other recent research. The paper is designed to direct future research initiatives required to establish new policy and confirm or amend existing policies.

\section{RESEARCH METHOD}

The research method was based on workshop exercises and the subsequent discussions undertaken by the selected group of experts. These expert researchers worked in groups to a structured methodology designed to identify the problems relating to retrofitting residential buildings together with their related causes and effects. From these data it was then possible to develop a series of research objectives. The objectives were presented in the form of an Objective Tree, a framework of research topics.

This methodology was based on the established technique commonly known as Problem Tree Analysis, a participatory tool for mapping out main problems, along with their causes and effects, supporting project planners to identify clear and manageable goals and the strategy of how to achieve them [13]. It is a proven approach to problem solving in business organisations, frequently used for strategic planning. It has been used by the authors for strategic planning with both small groups e.g. 10 people and large groups e.g. 150 people. The methodology ensures a holistic approach to the problem and seeks a wide perspective on all the issues relating to a topic and how they relate to one another. The authors consider it is ideally suited to discussing the complex inter-linked problems of the built environment. Its use in the context of establishing a research agenda is not common but the authors consider 
the approach to be a powerful tool that can establish consensus on research problems and then develop research objectives much faster than other traditional methods such as interviewing, surveys, use of the Delphi technique etc. [14].

All the researchers at the workshop were experts in topics relating to low carbon, energy saving, green building. Attendance for the meeting was by invitation only. There were 18 ' core members' of the group. Of these all had degree or equivalent qualifications and were members of professional institutions or associations. Seventeen had PhDs. in related topics. Eleven were Professors at leading academic institutions. The group was carefully selected on the basis the group would have a wide range of knowledge and not be biased towards any specific solution or approach to the problems to be discussed. In addition to the 'core' members there were some 7 other experts who attended for part of the meeting to contribute to specific discussions by providing contextual information e.g. climate change issues and the effects of the urbanisation. All the attendees could be considered 'stakeholders' in the sustainable built environment. They included: Architects; Building Scientists; an Economist, Construction Management experts; a Designer; a Materials Scientist; and government and industry representatives. They came from UK, Holland, Germany, Australia, South America, China, and Hong Kong. Careful selection of the experts ensured a multi-disciplinary approach to the problem.

The method followed a structured linear process that comprised eight stages. Each stage had specific actions: Preparation for the Workshop; the Provision of Contextual Information; Problem Analysis; Identifying the Objectives; Consolidation of the Objectives into a Single Objective Tree; Prioritization of Problems; Impact Analysis; and a Review of Workshop Outcomes. This is shown diagrammatically in Figure 1 which includes the actions and outcomes from each stage.

In preparation for the workshop all attendees were provided with identical information about the problem and invited to produce a short statement of their background and expertise and how this could contribute to the discussion. On the afternoon before the workshop a site visit was made to typical apartment buildings to familiarize the group with the high-rise living environment of the city and the layout of typical apartments. This was followed by the group members, the majority of which were unknown to one another, sharing information on their backgrounds. The workshop then took place over the following two days.

There was a joint review of the aims, objectives of the workshop and the expectations of the attendees. For the Problem Analysis stage the members were split into two teams devised to ensure a balance of talent in each team. (These teams were designated Team Alpha and Team Beta.) A period of individual reflection on the problems was followed by a brainstorming session where each group member identified specific problems relating to the subject area: 'The green retrofitting of high-rise residential buildings'. These problems were 'posted' on a large wall chart and then reviewed by the experts working in groups. Where there was an overlap between the problems two or more problems were consolidated into a single problem. Each group spent time evaluating the problem statements they had identified. Detailed consideration was given to each problem, its causes and effects. The problems were extended, combined, considered and restated. This iterative process continued for several hours. Each 
group produced a 'Problem Tree' by grouping the related problems in areas and linking them together where appropriate. This task occupied all the first day of the workshop.

Figure 2 shows the top level of the Problem Tree produced by one of the groups (Group Beta).

Figure 3 gives a breakdown of one of the problem areas from this problem tree showing the level of detail discussed.

Figures 4, 5, and 6 show further details of specific topics. These include: understand typical occupant energy use behaviour now and that predicted in the future; developing an economic argument to demonstrate the value and enable the retrofitting of residential buildings; and Understanding of institutional and legal structure and its implications.

Prior to Identifying the Research Objectives, the 'Problem Trees' produced by each group were reviewed by the Leader and Facilitator. An alignment table showing the consensus views of the experts was produced. This was presented to the researchers at the start of the second day. (The groups had not until then been aware of the others' problem analysis.) After lengthy discussion and some amendments all the experts agreed that this combined table represented a good summary of the problems relating to the green retrofitting of high-rise residential buildings.

Then followed the production of the Objective Tree designed to produce a structured summary of the research initiatives required.

It was agreed to work directly from the core data and alignment table to develop the research objectives. The experts were divided into two new teams Team X and Team Y. Each of the combined Core Problems was assigned to a single team; Team $\mathrm{X}$ worked on Problems A, C and E, whilst Team Y worked on Problems B, D, and F. The derivation of the Objective Analysis gives a 'means to an ends' relationship between the original problem definition and the subsequent objectives development. It provides a basis for the definition of a programme of activities to address the problems and to check alignment of objectives with the problems. This Objective Tree development requires consensus for alignment of working and in this workshop these penultimate sessions produced really valuable dynamic working in parallel, ensuring all the original causes and effects were fully considered in deriving core objectives and coherent sub-objectives. The international experts assessed each problem in turn and discussed and debated how the problems should be re-worded as an objective. To assist the discussion a group of 15 young researchers were introduced to the discussions with the brief to question the group members on their derivation of the objectives. This promoted both valuable rethinking, consolidation and re-alignment of the objectives and an innovative learning exercise for the students.

After a three-hour period of active discussion and representation the overall Objective Tree, named the Objective Analysis, was presented for discussion and confirmation. To enable this important conclusion to be fully explored a decision was made by the facilitators to extend the period allowed for the production of the analysis and not to move to the prioritization and impact phases. (Given more time the international experts would have been asked to prioritise the objectives and sub-objectives through a simple personal review and voting process where 
"value" is assigned to five coloured dots each which can be "spent" on those objectives which they consider a priority for action. This normally provides a useful steer for those charged with putting the plans into action in the Desktop Work phase of strategy development. A further exercise would have been to develop a strategic framework for action by completing an Impact Analysis for each objective. This is a useful way to create a programme of work and activities to address the workshop outcomes.)

In the last phase of the workshop there was an opportunity for all group members to discuss the key findings from the meeting. Both the findings from the workshop and the rationale behind these decisions were recorded. The Problem Trees and Objective Analysis produced by the group members were photographed to provide a permanent record. Discussion sessions were recorded on video and in audio format with contemporaneous notes to provide data to supplement the other data collected. Following the workshop meeting a draft report of the findings together with the data collected were to each expert who attended the workshop. This process took some two weeks. Each expert was given the opportunity to make factual amendments to the workshop report.

The final research objectives shown in the Objective Analysis were grouped under six main headings: overcome existing planning, design and construction limitations with respect to residential buildings; analyse the current situation in the city of Chongqing; develop an economic argument to demonstrate the value and enable the retrofitting of residential buildings; establish financial mechanisms and regulatory frameworks which shape refurbishment potential; design suitable Interventions that meet peoples' needs and promote a low energy life-style; policy decisions. They are summarized in Table 1 and presented as a research agenda to be read from vertically in each column from 1 to 7 . Some are iterative processes. This Objective Analysis formed the research agenda.

The experts agreed that the technique of using problem tree analysis to produce a research agenda was a useful approach that generated new ideas and provided a structured way of providing a holistic approach to the subject area.

The research agenda produced in Table 1 is a high-level agenda that supports earlier research findings [7] that the problems relating to retrofitting are not simply technical problems but predominantly social and economic problems. It is worth noting that of the six headings within the agenda shown in Table 1 three are marked as iterative emphasising the need to continually re-visit the topics. (It could be argued that all six of the research themes require an iterative approach.)

Table 1 is a framework for further analysis of the problems and the identification of specific research topics. The supporting information (see for example Figure 3) enables specific research questions to be identified. The exact nature of these research questions will be dependent on the type of residential building, the location and the climate type in that location plus detailed consideration of existing research findings.

\section{DISCUSSION OF RESEARCH TOPICS}




\section{Urbanization and retrofitting}

The experts recognized that China's continued economic growth is inexorably linked with urbanization. As urbanization and GDP growth continues the rate of energy consumption increases. This increase in energy demand is the result of increased wealth, changing lifestyles, increased consumer goods and rising expectations with respect to the availability of energy within the home and comfort. Greater expectations in thermal comfort result in more energy for heating in winter and more energy for cooling in summer. This is a particular issue in regions such as Chongqing where regional heating in winter is not permitted. This requirement is recognised by recently published research. See for example [15].

China recognises the importance of Green Building and the Green Building Council of China has identified three stages of green building development in the country: Energy Efficiency Building (commenced in 1995); Green Building (commenced in 2005); and the Development of Green Eco-Districts (commenced in 2009). Urbanisation means the priority for Green Building remains with the design and construction of new buildings. [16]. This does not mean that retrofitting is being ignored.

On 17th March 2016, the Ministry of Housing and Urban-Rural Development issued its 13th Five-Year Plan with proposed targets including promoting Green Buildings, building energy efficiency and the application of renewable energy in buildings. The plan for 2016 to 2020 recognizes that the rate of overall economic progress in China will change to a 'new normal' of between 6.5 and $7.0 \%$ per annum and refers directly to transforming the development pattern of cities, improving urban governance capacity and urban environmental quality, living quality and competitiveness, and striving to build a harmonious and liveable, vibrant, distinctive city [17]. Reconstruction of dilapidated buildings is a directly stated objective [2]. This commitment recognizes the importance of retrofitting and urban redevelopment and states that the proportion of Green Buildings in urban new buildings should exceed $50 \%$ by 2020. It also recognises the need to increase retrofitting of public and residential buildings. In 2017 the Ministry of Housing and Urban-Rural Development published its work plan for 2017. Experience from other countries has shown that the change of emphasis from new building to retrofitting will be more than simply a change of business focus, it will demand new construction skills and processes to be developed. (See for example [18] and [19].) and Similarly, China needs to identify new skills and promote appropriate training programmes. This work has already commenced [20].

\section{Improving the quality of the building stock}

Improving the quality of both new and existing building stock is considered essential. Rapid growth in the rate of new build residential housing inevitably leads to concerns about the quality of the building stock. Poor quality building stock is evidenced by poor design and poor construction that inevitably leads to the poor performance of the building envelope. These problems are widely recognized in China. An article that announced a new government 'green paper' on urbanization reported, 'Even as more than half of China's population lives in cities, China's urbanization drive has not given enough attention to quality through the years' [21]. 
Whilst some residential buildings in China are of very high standard many are not. Poor quality housing stock means housing that will require retrofitting earlier in the lifespan of the building. Problems also result from the lack of occupation of apartments. When purchased, construction on new apartments in China is seldom 'finished' in the same way that homes are completed prior to sale in other parts of the world. Items such as wall finishes and flooring are usually left for the owner to complete on occupation. Many apartments are purchased simply as investments or for future use by family members, and are left empty for years. If not occupied and properly maintained they quickly deteriorate [22].

The quality of construction depends on the development, publication and implementation of standards and regulations. This applies to both new construction and retrofitting. A comprehensive set of standards exists in China. These include the Assessment Standard for Green Building GB/T 50378-2014, [23] which applies to both new building and retrofitting. Such standards are produced at Government level but may be adapted at regional level to reflect local conditions. For example, in Chongqing the Chongqing Municipal Commission of Urban-Rural Development, announced the Design Standards on Public Building energy saving (green buildings) DBJ50-052-2016 which came into operation on 31th July 2016 [24]. Similarly, the Design Standards on Residential Building energy saving 65\% (green buildings) DBJ50-071-2016 on 1st Nov 2016 [25]. As with all standards and regulations the challenge is with their implementation.

\section{The need for economic models}

There is a clear need for better energy modelling and macro and a micro economic models to assess retrofitting solutions. Macro-economic problems that need to be investigated include the home ownership model, the lack of freehold ownership, and the nature of high-rise residential buildings that result in a large number of individual owners occupying a single apartment in a high-rise building. The needs of all the stakeholders must be considered. The problem is exacerbated by micro-economic problems including the lack of an economic argument to demonstrate the value of refurbishment at an individual level and the absence of financial models to support the argument for refurbishing. Retrofitting solutions usually comprise a number of different technologies so there is a need to assess the expected energy saving and the economic benefits across a range of technical combinations. Recent research relating to economic models for retrofitting includes [26] [27] [28] [29] [30] and [31].

Ma et al [31] review methodologies and the state-of-the art for retrofitting existing buildings. In terms of economic analysis, they note that the selection of retrofit measures is a trade-off between capital investment and benefits that can be achieved due to implementation of the retrofit measures. There are many studies related to economic analysis of building energy efficient measures. Remer and Nieto [32] identify that Net Present Value, (NPV), as the most typical technique for optimal building energy assessment among 25 techniques. Verbeeck and Hens [33] discuss the economic viability of different retrofit measures through the use of the NPV method. Peterson and Svendsen [34] use an economic optimisation method derived from 
the NPV method to determine the most cost effective energy efficiency measures. Nikolaidis et al. [35] employ four economic analysis methods, i.e. NPV, IRR, BCR, and DPP, to analyse energy saving measures in common types of Greek buildings. Huber et al. [36] studied the weights of social, cultural and economic factors in the decision-making process for implementing retrofits measures in domestic buildings.

Teresa-Zubiaga [27] highlight potential energy savings by implementing different energy saving measures to enhance the building envelope. These are presented and calculated through transient simulations using TRNSYS software. Different energy saving measures are defined for the roof, facade and windows, and 64 combinations are simulated. The results, which are evaluated under economic and energy criteria, are assessed using the reference of thermal requirements. The results from studies such as these demonstrate that economic assessment techniques can identify the most cost effective retrofit measures. This in turns aids the decision support process in making an optimal design of building retrofits. However, there does not appear to be a clear consensus on the methods to be adopted. Wang et al [26] found that despite great efforts to implement retrofit techniques no stringent evaluation of the benefits of these techniques or their systematic design has been completed. They note that traditional evaluations have not taken into account the embodied energy and greenhouse gases emissions of different retrofit options. This omission leads to underestimation of the potential environmental benefits of modern retrofit techniques. They propose a novel hybrid approach that uses life cycle assessment (LCA) techniques and integrate both energy demand (net operational energy), primary energy (operational energy from energy mix to buildings) into evaluation criteria. Embodied energy (energy required to produce materials of retrofitting options) and embodied greenhouse gas emissions (upstream $\mathrm{CO} 2$ equivalent) are introduced as new measures in the evaluation criteria.

Pombo et al [28] argue that whilst the technologies for retrofitting are understood well methods of assessment need further research. They review the current state of the art confirming the need to apply a lifecycle approach in order to find the optimal retrofitting solutions, and to identify the real improvement potential of housing renovation. Life cycle cost methodologies are analysed by discussing the existing limitations, which they argue can be mitigated by sensitivity analysis. Their review of available methods shows that, whilst social impacts were addressed in a few studies, life cycle social assessment is seldom addressed.

Dall et al [29] propose a methodology for evaluating the potential energy savings of retrofitting residential building stocks which considers both technological and economic constraints of the implementation of feasible energy efficiency measures. By detecting the characteristics of the building stock, they are able to assess which energy retrofit interventions are feasible from a technical, legal and economic point of view. A key difficulty is that the cost of refurbishment and the payback for the investment are not easy to quantify. The problems of evaluating the value secured by an investment are also difficult to quantify and assess. Similarly, there is a clear need for models to assess the high embedded energy of the resources used for construction and the monetary and low-carbon economics of demolition and re-build. Research such as that by Yip ae al, [37], has examined the economic viability of Green Building design for new buildings. Similar studies need to be undertaken for the 'green' retrofitting of high-rise residential building. 
The research agenda produced by the workshop and reported in this paper emphasises the need to identify and include in the economic models all the stakeholders concerned and identify incentives for investment, look at trials and projects. It is essential to evaluate the current situation with regard to ownership and funding.

It is not just economic models for the retrofitting technologies that are required. Sustainable business models also need to be produced for the construction companies who will undertake the work [30]. Traditional business models express the business logic of firms, they need to be extended to incorporate the 'triple bottom line', by embracing the economic, environmental and social dimensions. They first illustrate the state-of-the-art of business models for energy efficient retrofitting actions within the building field. Common business models are then described and compared in their main components, with an analysis of potentials and limitations.

\section{Requirements of residents}

Residents, whether they are owners or occupiers of buildings are important stakeholders and have a key role in the success of retrofitting. Minor refurbishments on apartments may be taken independently but deep retrofitting must be undertaken collectively. The failure of the 'Green Deal' initiative in the UK has been due to the lack of take up of the opportunities provided under the scheme by owners and occupiers of residential buildings. Put simply the 'Green Deal' was not seen as a 'good deal'. (See for example [38] and [39].)

A study of homeowners' views on energy retrofits across four European countries: Denmark, Latvia, Portugal and Belgium highlighted that although these different areas are all covered by the same regulation [6] designed to promote the opportunities for energy retrofitting lack of retrofitting practice is a result of (amongst other reasons) lack of shared know-how and lack of common goals amongst the relevant actors [6]. Evidence from resident surveys in Hong Kong [40] where high-rise buildings dominate the residential housing market has shown that residents/owners are reluctant to invest in major retrofitting works.

There are similar experiences in China. Liu et al [41] state that 'public participation in energy saving retrofitting is often neglected' and that, in the three retrofitting projects they studied, 'residents' responses varied'. They argue that to improve the effectiveness of retrofitting living habits must change and this will only happen when residents' needs are given full attention. Li et al [42] highlight the importance of user habits in sustainable refurbishment, accepting that the application of all the measures they investigated 'depends on residents' awareness of sustainability rather than the technical issues'. Lo, [43] investigated the 'Warm Houses Programme' in Changchun, Northern China. The research showed that the retrofitting of existing housing stock is possible but thermal retrofitting alone is not enough to promote energy saving. Providing households with the means and incentives for energy saving is important. Building inhabitants 'should not be treated as an afterthought and it is important to consider how practices of everyday life and practices of building retrofitting are linked'.

Although the importance of residents as stakeholders to successful retrofitting is recognised there is no evidence that there is a strong widespread appetite for sustainable retrofitting 
amongst the general public in China or in any other nation. What are the policies and incentives that can effect a change? Whilst residents will willingly embrace simple energy saving refurbishments such as replacement lighting they are reluctant to make changes to the building envelope preferring to move to larger, newer, higher status residences. There is a lack of similar studies amongst the residents of high-rise buildings in mainland China but studies relating to the introduction of new, environmentally technologies have shown a reluctance to embrace such solutions without clear evidence of direct economic benefits and these savings underwritten by government. See for example: Li et al, [44].

In the UK the challenges and opportunities of both funding and delivering housing refit on a community basis are detailed in the Joint Report produced by Arup and the institute of Sustainability [45]. The report finds that stakeholder engagement for community models needs to be extensive and involve a wide range of partners including tenant groups, social housing organisations and government. The main drivers for housing retrofit are comfort and/or improved asset values. Residents' perspectives are vital not only for initiating retrofitting but helping to ensure that the reconstructed building produce the energy savings envisaged [46]. Failure for reconstructed buildings to reach the levels of performance anticipated may be the result of changes in the behaviour of the residents that result in an even greater energy need. In the commercial sector, an analysis of the performance of new buildings constructed to 'green' standards showed that although certified buildings 'appear' to have an average actual performance above non-certified buildings in a number of cases, 'the actual performance may be significantly lower than standard forecasts' [47]. The following reasons are suggested for this gap between anticipated performance and actual performance: a difference in the use by occupants with standard forecasts, (in particular for the interior temperature and occupation duration); difficulties in the management and control of the technical installation; and the design or the development of the building and equipment that does not perform as well as expected once in place.

A review of pilot retrofitting projects for commercial buildings in China confirms that when retrofitting buildings, the energy savings are hard to assess and hard to verify [48]. There is no reason to belief that the situation will be any different with residential buildings. The changing energy needs of residents have attracted much research. Vivanco et al, [49] investigated the 'rebound effect', (where improvements in technological efficiency have induced increases in energy consumption), proposing and analysing mitigation strategies and policy pathways. Other studies highlight different aspects of user behaviour [48] have confirmed the importance of engaging residential energy customers' 'hearts and minds' and find that the most effective policies target behavioural, lifestyle and cultural factors to reduce energy consumption. They also found that cultural factors also have significant impact on residential energy demand.

Studies such as these support the experts' views at the workshop and highlight the need for extensive research into existing and prospective residential energy users' behaviour in China across all age groups and all backgrounds. It is essential to design suitable interventions that meet peoples' needs and promote a low energy life style.

\section{CONCLUSIONS AND RECOMMENDATIONS}


China faces the challenge of retrofitting its high-rise residential buildings. This retrofitting needs to be both a 'deep energy retrofit' with the emphasis on saving energy consumption through green technologies and sustainable building processes. A methodology based on Problem Tree Analysis proved an effective method of analysing the problem and producing an agenda for the research that is needed to facilitate such change. This research agenda identifies research needs under six headings: overcoming existing planning, design and construction limitations with respect to residential buildings; analysing the current situation in the city under study; developing an economic argument to demonstrate the value of retrofitting and enable the retrofitting of residential buildings; establishing financial mechanisms and regulatory frameworks which determine retrofitting potential; designing suitable intervention that meets people's needs and promotes a low energy life-style; and implementing policy decisions. Stages for undertaking the research activities under each of these headings have been identified. The agenda highlights that the challenge of retrofitting is holistic and includes not just engineering and construction actions but economic, social and governmental requirements.

Policy considerations are core to the successful retrofitting of residential buildings. New building developments remain the current focus of building in China but retrofitting is not ignored. China's recent 5-Year Plans have directed both the pace and focus of retrofitting. Since the start of the 13th 5 year plan in March 2016 reconstruction is set to increase. Improving the quality of both new and existing building stock is considered essential. There is a clear need for better energy modelling and macro and a micro economic models to assess retrofitting solutions.

Future energy consumption is highly dependent upon the lifestyle of the residents and policies need to be introduced to encourage energy saving and promote residential energy saving methods. Residents, whether they are owners or occupiers of buildings are important stakeholders and have a key role in the success of retrofitting. There is a clear need for extensive research into existing and prospective residential energy users' behaviour across all age groups and all backgrounds. It is essential to design suitable interventions that meet peoples' needs and promote a low energy life style. These actions will present different challenges to different cities in China depending upon their climatic region, their current programmes for high-rise residential building, and the data on building stock currently available. Different cities in different climatic regions will have different problems and different solutions.

\section{Acknowledgements}

The authors would like to acknowledge the contribution of the researchers who participated in the workshop and all those who contributed to the discussion, data collection and analysis. The research was undertaken in conjunction with The National Centre for International Research of Low-carbon and Green Buildings, Joint International Research Laboratory of Green Building and Built Environment (Ministry of Education) Chongqing University. The research reported in this paper was supported funded under the ' 1000 Talents Scheme' of the Organisation Department of the Central Committee of the CPC Ministry of Human Resources and Social Security of the P.R.C., the Municipality of Chongqing, and Chongqing University. 


\section{Figures and Tables}

\section{Figure 1- The Workshop Methodology}

\begin{tabular}{|c|c|c|c|}
\hline & STAGE & ACTIONS AND OUTCOMES & NOTES \\
\hline 1 & Prepare for the Workshop & $\begin{array}{l}\text { Select the Group Leader. Select a suitable group of experts } \\
\text { to address the subject area. Select an experienced } \\
\text { facilitator. Formulate a clear statement of the problem. } \\
\text { Identify the Aims and Objectives of the study. Allocate a } \\
\text { suitable location and a suitable timescale for the event. } \\
\text { Prepare a detailed programme for the allocated time. }\end{array}$ & $\begin{array}{l}\text { To ensure a suitable group of } \\
\text { experts these actions may need to } \\
\text { be commenced one year in } \\
\text { advance of the event. The } \\
\text { programme should be prepared by } \\
\text { the Leader and the Facilitator. }\end{array}$ \\
\hline 2 & $\begin{array}{l}\text { Provide Contextual Data } \\
\text { and Information Set }\end{array}$ & $\begin{array}{l}\text { Provide sufficient support material (papers, photographs, } \\
\text { reports etc.) to enable the experts to consider the } \\
\text { problem area. Arrange location visits. Enable the experts } \\
\text { share their background and subject knowledge. }\end{array}$ & $\begin{array}{l}\text { The experts will need background } \\
\text { information on the problem. } \\
\text { Provide information to experts six } \\
\text { weeks before the event. At the } \\
\text { start of the event hold an 'ice- } \\
\text { breaker' session so that the experts } \\
\text { learn about each other before the } \\
\text { event. }\end{array}$ \\
\hline 3 & The Problem Analysis & $\begin{array}{l}\text { Divide the experts into teams. Allow silent individual } \\
\text { reflection on the problem. Brainstorm the problem as a } \\
\text { group. Post problems on a wallchart. Review problems. If } \\
\text { problems overlap, consolidate. Consider causes and } \\
\text { effects. Allow detailed discussion and iteration. Repeat } \\
\text { until a consensus is reached within each group. (Each } \\
\text { group shares their Problem Tree with the other group } \\
\text { members.) Produce a Single Problem Tree. Obtain } \\
\text { consensus amongst all experts. }\end{array}$ & $\begin{array}{l}\text { In this workshop the } 18 \text { core } \\
\text { experts were divided into two } \\
\text { equal teams. } \\
\text { The Problem Analysis took some } \\
\text { four hours. Each team worked in } \\
\text { isolation until their Problem Tree } \\
\text { was completed. In this exercise in } \\
\text { place of a Single Problem Tree the } \\
\text { Facilitator and Leader produced an } \\
\text { Alignment Table. }\end{array}$ \\
\hline 4 & Objective Analysis & $\begin{array}{l}\text { Determine a structured summary of Objectives (research) } \\
\text { initiatives required. Develop these objectives from the } \\
\text { Single Problem Tree referring back to the core causes, } \\
\text { problems and effects. }\end{array}$ & $\begin{array}{l}\text { The experts were divided into two } \\
\text { different groups } X \text { and } Y \text {. They } \\
\text { worked from the alignment table } \\
\text { with reference to the detailed data } \\
\text { in each Problem Tree. }\end{array}$ \\
\hline 5 & $\begin{array}{l}\text { Consolidation of the } \\
\text { Objectives into a Single } \\
\text { Objective Tree }\end{array}$ & $\begin{array}{l}\text { Establish a Single Objective Statement and check that the } \\
\text { objectives and sub-objectives are aligned with the } \\
\text { problems. }\end{array}$ & $\begin{array}{l}\text { This exercise took some four hours } \\
\text { of detailed discussion and review. }\end{array}$ \\
\hline 6 & $\begin{array}{l}\text { Prioritization of the } \\
\text { Objectives }\end{array}$ & $\begin{array}{l}\text { Prioritize the Objectives ( and Sub-Objectives ) by } \\
\text { discussion amongst the experts of a simple voting process. }\end{array}$ & $\begin{array}{l}\text { This task was not undertaken in the } \\
\text { workshop. A decision was made to } \\
\text { leave this task to 'local' experts. }\end{array}$ \\
\hline 7 & Impact Analysis & $\begin{array}{l}\text { Develop a strategic framework for action by completing an } \\
\text { Impact Analysis for each Objective. Create a programme of } \\
\text { work and activities to address the workshop outcomes. }\end{array}$ & $\begin{array}{l}\text { This task was not undertaken in the } \\
\text { workshop. A decision was made to } \\
\text { leave this task to 'local' experts. }\end{array}$ \\
\hline 8 & $\begin{array}{l}\text { Review Workshop } \\
\text { Outcomes and Report }\end{array}$ & $\begin{array}{l}\text { Discuss the overall effectiveness of the workshop process. } \\
\text { Produce a draft report and circulate for each expert to } \\
\text { review and make factual amendments. Consolidate and } \\
\text { make a final report. }\end{array}$ & $\begin{array}{l}\text { The workshop report was produced } \\
\text { by the Facilitator in conjunction } \\
\text { with the Leader. 'Mindmap' } \\
\text { software was used to model the } \\
\text { data in the Problem Trees. }\end{array}$ \\
\hline
\end{tabular}


Figure 2 - An example of the top level of the problem tree produced by one of the groups

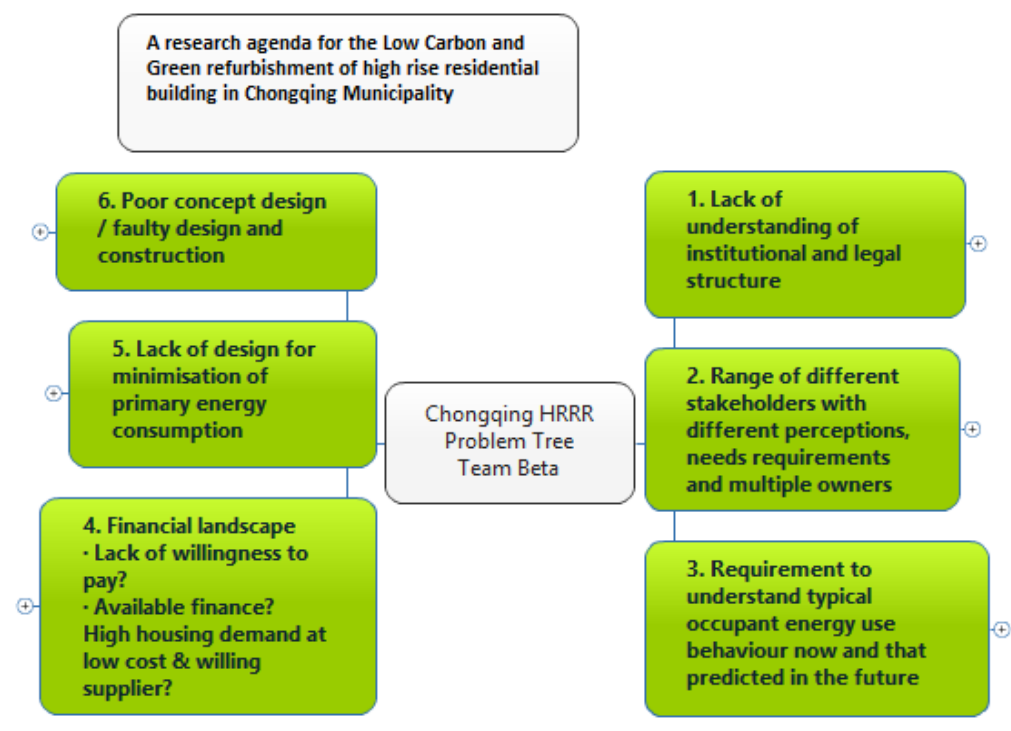


Figure 3 A breakdown of one of the problem areas in the Problem Tree of Group Beta.

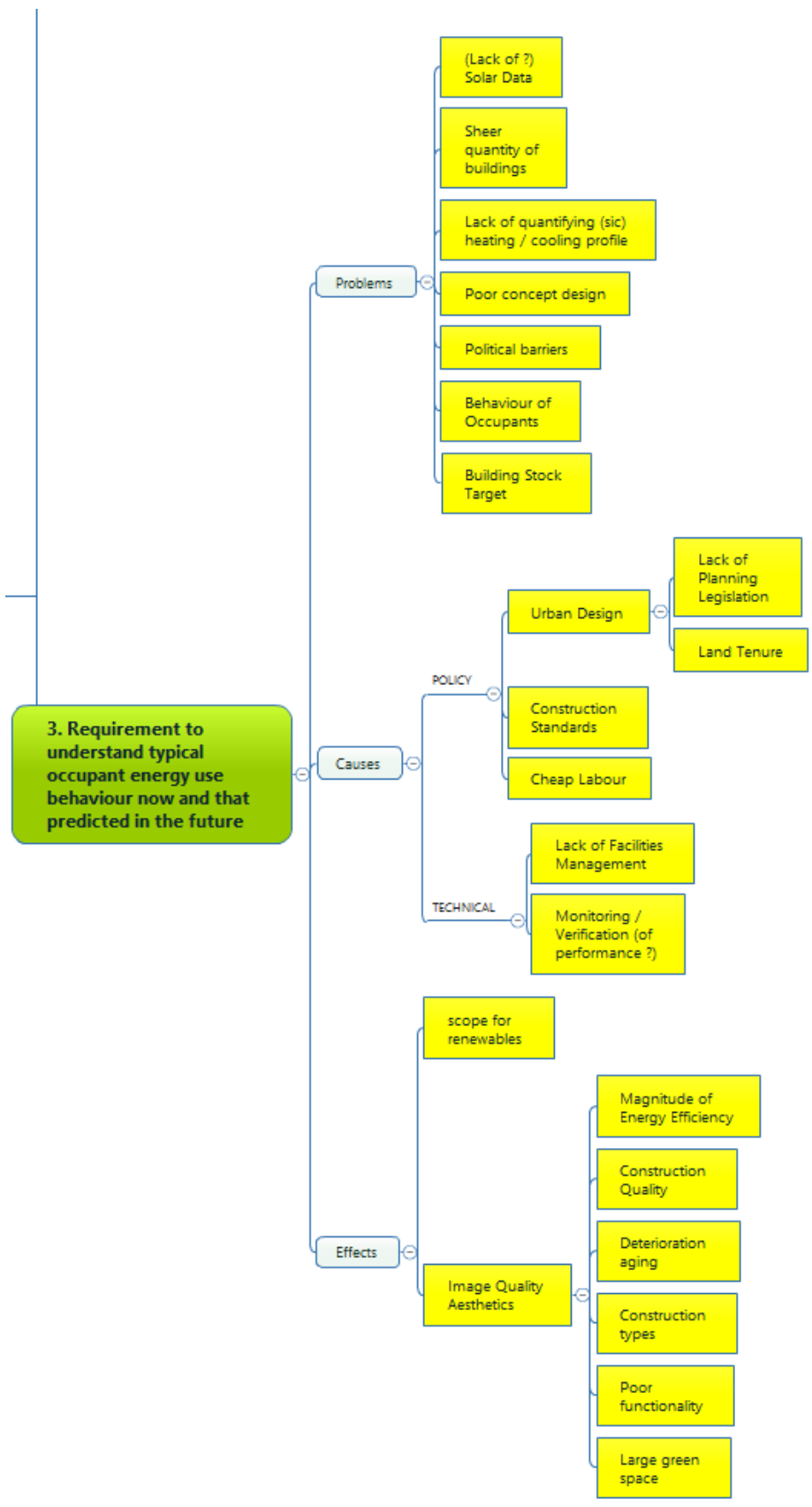


Figure 4 - Team Beta- Requirement to understand typical occupant energy use behaviour now and that predicted in the future

\begin{tabular}{|c|c|c|c|c|c|}
\hline PROBLEMS & CAUSES & & & EFFECTS & \\
\hline $\begin{array}{l}\text { Lack of } \\
\text { data }\end{array}$ & POLICY & $\begin{array}{l}\text { Urban } \\
\text { Design }\end{array}$ & $\begin{array}{l}\text { Lack of } \\
\text { Planning } \\
\text { Constraint }\end{array}$ & $\begin{array}{l}\text { Scope for } \\
\text { renewables }\end{array}$ & \\
\hline $\begin{array}{l}\text { Sheer } \\
\text { quantity of } \\
\text { buildings } \\
\end{array}$ & & & $\begin{array}{l}\text { Land } \\
\text { Tenure }\end{array}$ & $\begin{array}{l}\text { Image / } \\
\text { Quality } \\
\text { /Aesthetics }\end{array}$ & $\begin{array}{l}\text { Magnitude } \\
\text { of energy } \\
\text { efficiency }\end{array}$ \\
\hline $\begin{array}{l}\text { Lack of } \\
\text { data on } \\
\text { heating/ } \\
\text { cooling } \\
\text { costs } \\
\text { profile }\end{array}$ & & $\begin{array}{l}\text { Construction } \\
\text { Standards }\end{array}$ & & & $\begin{array}{l}\text { Construction } \\
\text { Quality }\end{array}$ \\
\hline $\begin{array}{l}\text { Poor } \\
\text { Concept } \\
\text { Design }\end{array}$ & & $\begin{array}{l}\text { Cheap } \\
\text { Labour }\end{array}$ & & & $\begin{array}{l}\text { Deterioration } \\
\text { and ageing }\end{array}$ \\
\hline $\begin{array}{l}\text { Political } \\
\text { Barriers }\end{array}$ & & & & & $\begin{array}{l}\text { Poor } \\
\text { functionality }\end{array}$ \\
\hline $\begin{array}{l}\text { Behaviour } \\
\text { of } \\
\text { occupants }\end{array}$ & TECHNICAL & $\begin{array}{l}\text { Lack of } \\
\text { Facilities } \\
\text { Management }\end{array}$ & & & \\
\hline $\begin{array}{l}\text { Building } \\
\text { stock } \\
\text { target }\end{array}$ & & $\begin{array}{l}\text { Monitoring } \\
\text { /Verification } \\
\text { of } \\
\text { Performance }\end{array}$ & & & \\
\hline
\end{tabular}


Figure 5 - Team Alpha - Developing an economic argument to demonstrate the value and enable the retrofitting of residential buildings

\begin{tabular}{|c|c|c|c|c|}
\hline PROBLEMS & CAUSES & & & EFFECTS \\
\hline $\begin{array}{l}\text { Cost of } \\
\text { refurbishment }\end{array}$ & POLICY & $\begin{array}{l}\text { Low income } \\
\text { Limited } \\
\text { budget }\end{array}$ & $\begin{array}{l}\text { Lack of } \\
\text { Planning } \\
\text { Constraint }\end{array}$ & Affordability \\
\hline $\begin{array}{l}\text { Payback } \\
\text { difficult to } \\
\text { quantify }\end{array}$ & & $\begin{array}{l}\text { Planning } \\
\text { and } \\
\text { regulations }\end{array}$ & $\begin{array}{l}\text { Land } \\
\text { Tenure }\end{array}$ & $\begin{array}{l}\text { High } \\
\text { embedded } \\
\text { resources / } \\
\text { energy/ } \\
\text { carbon }\end{array}$ \\
\hline $\begin{array}{l}\text { Value vs } \\
\text { Investment }\end{array}$ & ENVIRONMENTAL & $\begin{array}{l}\text { Resource } \\
\text { shortage }\end{array}$ & & $\begin{array}{l}\text { Economics of } \\
\text { development } \\
\text { and } \\
\text { rebuilding }\end{array}$ \\
\hline \multirow[t]{5}{*}{$\begin{array}{l}\text { Low worth of } \\
\text { building fabric }\end{array}$} & SOCIAL & $\begin{array}{l}\text { Increase in } \\
\text { wealth } \\
\text { GDP }\end{array}$ & & \\
\hline & TECHNICAL & $\begin{array}{l}\text { Lack of } \\
\text { advanced } \\
\text { construction } \\
\text { skills }\end{array}$ & $\begin{array}{l}\text { Building } \\
\text { industry } \\
\text { practice }\end{array}$ & \\
\hline & & & $\begin{array}{l}\text { Building } \\
\text { skills }\end{array}$ & \\
\hline & & & $\begin{array}{l}\text { Low skill } \\
\text { base }\end{array}$ & \\
\hline & & $\begin{array}{l}\text { Lack of } \\
\text { knowledge }\end{array}$ & $\begin{array}{l}\text { Lack of } \\
\text { data to } \\
\text { quantify } \\
\text { the } \\
\text { problem }\end{array}$ & \\
\hline
\end{tabular}


Figure 6 - Team Beta- Understanding of institutional and legal structure and its implications

\begin{tabular}{|l|l|l|l|l|l|l|}
\hline PROBLEMS & & CAUSES & & & EFFECTS & \\
\hline $\begin{array}{l}\text { Multiple } \\
\text { Owners }\end{array}$ & & POLICY & $\begin{array}{l}\text { Urban } \\
\text { Design }\end{array}$ & $\begin{array}{l}\text { Lack of Planning } \\
\text { Constraint }\end{array}$ & $\begin{array}{l}\text { Image } \\
\text { Quality / } \\
\text { Aesthetics }\end{array}$ & $\begin{array}{l}\text { Magnitude } \\
\text { of Energy } \\
\text { Efficiency }\end{array}$ \\
\hline $\begin{array}{l}\text { Societal } \\
\text { Perception }\end{array}$ & & & Land Tenure & & $\begin{array}{l}\text { Construction } \\
\text { quality }\end{array}$ \\
\hline $\begin{array}{l}\text { Cultural } \\
\text { barriers }\end{array}$ & & & $\begin{array}{l}\text { Construction } \\
\text { Standards } \\
\text { / Ageing }\end{array}$ \\
\hline $\begin{array}{l}\text { Stakeholder } \\
\text { Diversity }\end{array}$ & & $\begin{array}{l}\text { Cheap } \\
\text { Labour }\end{array}$ & & $\begin{array}{l}\text { Construction } \\
\text { types }\end{array}$ \\
\hline & & SOCIAL & Urbanisation & $\begin{array}{l}\text { Increasing } \\
\text { Expectations }\end{array}$ & $\begin{array}{l}\text { Poor } \\
\text { functionality }\end{array}$ \\
\hline & & & Population Growth & Space \\
\hline & & $\begin{array}{l}\text { Industry } \\
\text { Perception }\end{array}$ & Supply/Demand & & \\
\hline & & & Need/Space/Quantity & & \\
\hline & & $\begin{array}{l}\text { High } \\
\text { Demand / } \\
\text { Ready } \\
\text { Supply/ } \\
\text { Low costs }\end{array}$ & $\begin{array}{l}\text { Suitable } \\
\text { Technologies }\end{array}$ & & & \\
\hline & & & & & \\
\hline & & & & & \\
\hline
\end{tabular}


Table 1- A Research Agenda for Low -carbon and Green Refurbishment of High-rise Residential Buildings in China

\begin{tabular}{|c|c|c|c|c|c|c|}
\hline & $A$ & $B$ & $\mathrm{C}$ & $D$ & $E$ & $F$ \\
\hline & $\begin{array}{l}\text { Overcoming } \\
\text { existing planning, } \\
\text { design and } \\
\text { construction } \\
\text { limitations with } \\
\text { respect to } \\
\text { residential } \\
\text { buildings }\end{array}$ & $\begin{array}{l}\text { Analysing } \\
\text { the current } \\
\text { situation in } \\
\text { the city } \\
\text { under study }\end{array}$ & $\begin{array}{l}\text { Developing an } \\
\text { economic } \\
\text { argument to } \\
\text { demonstrate } \\
\text { the value and } \\
\text { enable the } \\
\text { retrofitting of } \\
\text { residential } \\
\text { buildings }\end{array}$ & $\begin{array}{l}\text { Establishing } \\
\text { financial } \\
\text { mechanisms } \\
\text { and } \\
\text { regulatory } \\
\text { frameworks } \\
\text { which shape } \\
\text { refurbishment } \\
\text { potential }\end{array}$ & $\begin{array}{l}\text { Designing } \\
\text { suitable } \\
\text { Interventions } \\
\text { that meet } \\
\text { peoples' } \\
\text { needs and } \\
\text { promote a } \\
\text { low energy } \\
\text { life-style }\end{array}$ & $\begin{array}{l}\text { Implementing Policy } \\
\text { Decisions }\end{array}$ \\
\hline 1 & $\begin{array}{l}\text { Establish baseline } \\
\text { data that arise } \\
\text { from existing } \\
\text { buildings }\end{array}$ & $\begin{array}{l}\text { Undertake a } \\
\text { public } \\
\text { perception } \\
\text { survey } \\
\text { including } \\
\text { views on a } \\
\text { healthy } \\
\text { environment }\end{array}$ & $\begin{array}{l}\text { Identify the } \\
\text { potential } \\
\text { stakeholder } \\
\text { and their } \\
\text { interest, } \\
\text { identify } \\
\text { incentives for } \\
\text { investment, } \\
\text { look at trials } \\
\text { and projects }\end{array}$ & $\begin{array}{l}\text { Conduct } \\
\text { public } \\
\text { perception } \\
\text { survey } \\
\text { including } \\
\text { willingness to } \\
\text { pay, } \\
\text { affordability }\end{array}$ & $\begin{array}{l}\text { Establish } \\
\text { baseline data } \\
\text { from existing } \\
\text { households, } \\
\text { understand } \\
\text { the context of } \\
\text { use }\end{array}$ & $\begin{array}{l}\text { Understand current driving } \\
\text { force and policy for } \\
\text { implementing change in the } \\
\text { city under study }\end{array}$ \\
\hline 2 & $\begin{array}{l}\text { Evaluate the } \\
\text { current situation } \\
\text { including the } \\
\text { planning } \\
\text { regulations with } \\
\text { regard t the } \\
\text { retrofit of } \\
\text { residential } \\
\text { building }\end{array}$ & $\begin{array}{l}\text { Conduct } \\
\text { stock } \\
\text { analysis } \\
\text { including } \\
\text { existing } \\
\text { buildings } \\
\text { people, } \\
\text { demand and } \\
\text { environment }\end{array}$ & $\begin{array}{l}\text { Evaluate the } \\
\text { current } \\
\text { situation with } \\
\text { regard to } \\
\text { ownership and } \\
\text { funding }\end{array}$ & $\begin{array}{l}\text { Understand } \\
\text { Joint } \\
\text { ownership } \\
\text { framework } \\
\text { (sinking funds) }\end{array}$ & $\begin{array}{l}\text { Evaluate } \\
\text { people's } \\
\text { current } \\
\text { practices, } \\
\text { behaivours, } \\
\text { aspirations } \\
\text { and } \\
\text { expectations }\end{array}$ & $\begin{array}{l}\text { Effect Coordination between } \\
\text { planning/construction/science } \\
\text { and technology bureau }\end{array}$ \\
\hline 4 & $\begin{array}{l}\text { Recommend } \\
\text { existing building } \\
\text { retrofit scope and } \\
\text { timeline }\end{array}$ & $\begin{array}{l}\text { Establish a } \\
\text { precedent } \\
\text { through } \\
\text { informed } \\
\text { scoping } \\
\text { study, } \\
\text { feasibility } \\
\text { study, and } \\
\text { socio- } \\
\text { economic } \\
\text { impact study }\end{array}$ & $\begin{array}{l}\text { Recommend } \\
\text { funding models } \\
\text { and policies } \\
\text { that may } \\
\text { support their } \\
\text { implementation }\end{array}$ & $\begin{array}{l}\text { Consider } \\
\text { approvals, } \\
\text { Building } \\
\text { Regulations, } \\
\text { Health and } \\
\text { Safety at } \\
\text { Work } \\
\text { (Construction } \\
\text { activity) to } \\
\text { establish } \\
\text { constraints. }\end{array}$ & $\begin{array}{l}\text { Forecast } \\
\text { future change } \\
\text { in line with } \\
\text { change in } \\
\text { demographics } \\
\text { and } \\
\text { technological } \\
\text { development }\end{array}$ & \\
\hline 5 & $\begin{array}{l}\text { Demonstrate } \\
\text { recommendations } \\
\text { work through } \\
\text { case studies }\end{array}$ & $\begin{array}{l}\text { Undertake a } \\
\text { Stock } \\
\text { modelling } \\
\text { exercise }\end{array}$ & $\begin{array}{l}\text { Demonstrate } \\
\text { that the models } \\
\text { work through a } \\
\text { coordinated } \\
\text { programme of } \\
\text { case studies }\end{array}$ & & $\begin{array}{l}\text { Recognize } \\
\text { solutions to } \\
\text { raise } \\
\text { awareness } \\
\text { and } \\
\text { engagement }\end{array}$ & \\
\hline 6 & $\begin{array}{l}\text { Enable the } \\
\text { implementation } \\
\text { through training } \\
\text { education, review } \\
\text { of supply chain }\end{array}$ & $\begin{array}{l}\text { Establish } \\
\text { current } \\
\text { construction } \\
\text { staff skills } \\
\text { and training } \\
\text { needs }\end{array}$ & $\begin{array}{l}\text { Enable the } \\
\text { implementation } \\
\text { of those } \\
\text { funding models } \\
\text { through } \\
\text { targeted } \\
\text { marketing }\end{array}$ & & $\begin{array}{l}\text { Demonstrate } \\
\text { the } \\
\text { effectiveness } \\
\text { of the } \\
\text { solutions } \\
\text { through a } \\
\text { coordinated }\end{array}$ & \\
\hline
\end{tabular}




\section{References}

[1] CGPRC, Central Government of People's Republic of China - China's New Urbanization Plan (2014-2020) (2014) at http://www.gov.cn/zhengce/2014-03/16/content_2640075.htm accessed 2016/06/20

[2] Zhang, J. Caution on reform, growth remains key objective - Full Coverage of 2016 NPC and CPPCC sessions in China Daily (2016) accessed from

http://english.cntv.cn/2016/03/07/ARTlrD4h1c2XnceFzKhSRW19160307.shtml Accessed 08 March 2016

[3] Li B., and Yao, R., Urbanisation and its impact on building energy consumption and efficiency in China, Renewable Energy Vol 34 (2009) 1994-1998, doi:

10.1016/j.renene.2009.02.015

[4] Liang J., Li, B., Wu, Y., Yao, R., An investigation of the existing situation and tends in building energy efficiency management in China, Energy and Buildings Vol 39 (2007) 10981106, doi: 10.1016/j.enbuild.2006.12.002

[5] Gao W., Wang, X., Li, H., Zhao, P., Ren, J. Toshio, O. Living environment and energy consumption in cities of Yangste Delta Area, Energy and Buildings, Vol 36 (2004) 1241-1246, doi:10.1016./jenbuild.2003.10.012

[6] EU Directive 2010/31/EU of the European Parliament of the Council of 19 May 2010 on the energy performance of buildings (recast) European Union (2010), and available at: http://www.eceee.org/policy-areas/buildings/EPBD_Recast/EPBD_recast_19May2010.pdf accessed April 2016

[7] CII-HK, Solutions Implementation of Healthy Buildings in Hong Kong, a report produced by the Construction Industry Institute of Hong Kong, CII-HK, (2005) and published by the Hong Kong Polytechnic and CII-HK.

[8] Loveday, D.L., and Vadodaria, K., editors Project CALEBRE- Consumer Appealing Low Energy Technologies for Building Retrofitting, (2013), published by Loughborough University,

Loughborough, UK ISBN 978-1-907382-68-0

[9] Shah, S., Sustainable Refurbishment (2012) Wiley Blackwell, Chichester, West Sussex, UK ISBN 978-1-4051-9508-9

[10] Gillott, M., Loveday, D.L., and Vadodaria, K., (2013) Airtightness Improvements and Ventilation Systems in Domestic Refurbishment, in Project CALEBRE (Consumer Appealing Low Energy technologies for Building Retrofitting) a summary report edited by Loveday, D.L.L and Vadodaria, K. and published by Loughborough University, Loughborough, UK. ISBN 978-1-907382-68-0

[11] EPA -U.S. Environmental Protection Agency. (2009). Green Building Basic Information. Retrieved December 10, 2009, from http://www.epa.gov/greenbuilding/pubs/about.htm

[12] Hakkinen, T., Systematic method for the sustainability analysis of refurbishment concepts of exterior walls, Construction and Building Materials 37 (2012) 783-790

[13] Dillion, L.B., 'Problem Analysis' at Sustainable Water and Energy Management (2017), http://www.sswm.info/category/planning-process-tools/exploring/exploring-

tools/preliminary-assessment-current-status/prob accessed 2017/05/20

[14] Bryman, A., and Bell, E., Business Research Methods, 3 $3^{\text {rd }}$ Edition, (2007) Oxford University Press, Oxford, UK, ISBN 978-0-19-958340-9 
[15] Hu, T., H. Yoshino, and Z. Jiang, Analysis on urban residential energy consumption of Hot Summer; Cold Winter Zone in China. Sustainable Cities and Society, 6(1): (2013), pp. 8591.

[16] Wang Y, 'Challenges of Net-Zero Projects' presentation made to the inaugural meeting of the China Green Building Council UK Chapter, Reading University, April, 2017.

[17] CGPRC. 13th Five-Year Plan for Economic and Social Development of the People's Republic of China (the 13th Five-Year Plan) - The Central Government of the People's Republic of China accessed from the government website 2016/04/04 http://www.gov.cn/xinwen/2016-03/17/content_5054992.htm on April 042016.

[18] Dainty, A., Thompson, D. and Fernie, S. 'Closing the performance gap in the delivery of zero-carbon homes: A collaborative approach' presented at the Conference of Construction and Housing in the 21st Century 12-13 May (2013) Hong Kong and also available via the Loughborough University Institutional repository- https://dspace.lboro.ac.uk/2134/12136 accessed 05 April 2016

[19] Fernie, S. and Tennant, S. Theory to practice; a typology of supply chain management in construction International Journal of Construction Management, Vol 14, (1) (2014) 55-66 also available via the Loughborough University Institutional repository-

https://dspace.lboro.ac.uk/2134/17724 accessed 05 April 2016

[20] Wang Q. Green Building and Green Retrofitting presentation made to the SBE16 Conference at Chongqing University, China (2016).

[21] Wei, H. China's urbanization lacks quality, equality (2012),

See http://usa.chinadaily.com.cn/china/2012-09/15/content_15760607.htm accessed July 2016 published jointly by the Centre of Science and Technology of Construction Ministry of Housing and Urban Rural Development, People's Republic of China and the Centre of Urban Planning and Design, Peking University, P.R. China. ISBN 978-7-112-15200-1

[22] Schmidt III, R., Baldwin, A.N., Zhang, C., Accelerated Creep(ing): A ‘buy \& forget' mentality for Chinese homes accepted for publication in Dichotomy 22 (Creep) the Journal of the School of Architecture, The University of Detroit Mercy, (2016) accessible at: https://issuu.com/dichotomyudm/docs/dichotomy_22-_creep_issuu in July 2016

[23] People's Republic of China, Assessment Standard for Green Building, GB/T 50378-2014, (2014) available from www.china-building.com.cn

[24] People's Republic of China, Design Standards on Public Building energy saving (green buildings) DBJ50-052-2016, (2016) published by Chongqing the Chongqing Municipal Commission of Urban-Rural Development, available from www.china-building.com.cn

[25] People's Republic of China, Design Standards on Residential Building Energy Saving (green buildings) DBJ50-071-2016 (2016) available from www.china-building.com.cn [26] Wang, Q., Luarenti, R., Holmberg, S., A novel hybrid methodology to evaluate sustainable retrofitting in existing Swedish residential buildings Sustainable Cities and Society 16, (2015) 24-38

[27] Teres-Zubiaga, J., Campos-Celador, A., Gonzalez-Pino, I., and Escudero-Revilla, C. (2015), 'Energy and economic assessment of the envelope retrofitting in residential buildings in Northern Spain,' Energy and Buildings, 86, (2015), 194-202

[28] Pombo, O., Rivela, B., Neila, J., The challenge of sustainable building renovation: assessment of current criteria and future outlook in Journal of Cleaner Production, 123. (2016), 88-100 
[29] Dall 'O G., Galante, A., and Pasetti, G., A methodology for evaluating the potential energy savings of retrofitting residential building stocks, sustainable Cities and Society 4 ( (2012) 112-21

[30] Moschetti R., Brattebø H., Sustainable business models for deep energy retrofitting of buildings: state-of -the -art and methodological approach. Energy Procedia 96 (2016) pp435-445

[31] Ma, Z., Cooper, P., Daly, D., Ledo, L., Existing building retrofits: Methodology and state-of-the-art. Energy and Buildings, 55, (2012) 889-902

[32] Remer, D.S., and Niet, A.P., A compendium and comparison of 25 project evaluation techniques. Part 1. Net present value and the rate of return methods, International Journal of Production Economics, 42, (1995), 79-96.

[33] Verbeeck, G., and Hens, H., Energy savings in retrofitted buildings: economically viable, Energy and Buildings, 37, (2005,) 747-754

[34] Peterson, S., and Svendsen, S., Method for component-based economical optimisation for use in the design of new low-energy buildings, Renewable Energy, 38, (2012), 173-180 [35] Nikolaidis, Y., Pilavachi, P.A., Chletsis A., Economic evaluation of energy saving measure in a common type of Greek Building, Applied Energy 86 (2009) 2550-2559

[36] Huber, A., Mayer, I., Beillan, V., Refurbishing residential buildings: a socio-economic analysis of retrofitting projects in five European countries in World Sustainable Energy Days 2011, (2011) available at ww.fedarene.org/documents/projects.

[37] Yip, S., Li, H., and Ling S., Study on the economics of green buildings in China, report of the China Sustainable Energy Program of the Energy Foundation (2013) ISBN 978-7-11215200-1

[38] CPA, What went wrong with the Green Deal' the Consumer Protection Association, 25 March 2014 available at http://www.thecpa.co.uk/what-went-wrong-green-deal/

[39] Construction Index Figures Reveal the Extent of Green Deal Failure', the Construction Index,UK, 22 January 2014, at http://www.theconstructionindex.co.uk/news/view/figuresreveal-extent-of-green-deal-failure

[40] Ng T., Gong, W., and Loveday, D.L., Sustainable refurbishment methods for uplifting the energy performance of high-rise residential buildings in Hong Kong', in Procedia Engineering Vol 85 (2014), 385-392, doi:10.1016/j.proeng.2014.10.564

[41] Liu W., Zhang, J., Bluemling, B., Mol, A.P. J., and Wang, C., Public participation in energy saving retrofitting of residential buildings in China, Applied Energy and Buildings 147 (2015) 287-296

[42] Li, J., Ng, S.T., Skitmore, M., Review of low-carbon refurbishment solutions for residential buildings with particular reference to multi-story buildings in Hong Kong Renewable and Sustainable energy reviews 73 ( 2017) 393-407

[43] Lo, K. The warm Houses program: insulating existing buildings through compulsory retrofits. Technical Note in Sustainable Energy Technologies and Assessments 9 (2015) 63-67 
[44] Li X., Li H, and Wang X, Farmers' willingness to convert house to solar houses in rural areas: a survey of 465 households in China. Energy Policy 63 (2013) p882-886

[45] IOS, Delivering and funding housing refit: a review of community models (2013) a report produced by Arup and Institute of Sustainability and available via www.institutefor sustainability.co.uk

[46] Carassus, J., Are Green Office Buildings Keeping their Promises? a study published by iiSBE (2011), and accessed via www.iisbe.org website 2016/07/23

http://www.iisbe.org/system/files/private/Green_promises_Carassus_2011.pdf

[47] Hou, J., Liu, Y., Wu, Y., Zhou, N., Feng, W., (2016), Comparative study of commercial buildings energy-efficiency retrofit policies in four pilot cities in China" Energy Policy Vol .88 pp 2014-215 Hong Kong Green Building Council, (2104), 'Hong Kong Report on the State of Sustainable Built Environment,2014' A report published by the Construction Industry Council and the Hong Kong Green Building Council, Hong Kong, P.R. China, 2014, ISBN 9-789881268495

[48] Olaniyan, M.J., and Evans, J., The importance of engaging residential energy customers' hearts and minds' in Energy Policy Volume 69, (2014), pp 273-284,

doi:10.1016/j.enpol.2013.12.023

[49] Vivanco, D.F., Kemp, R., von de Voet, E., How to deal with the rebound effect? a

policy-orientated approach Energy Policy, Vol 94, (2016) pp114-125 